\title{
Traditional knowledge among Zapotecs of Sierra Madre Del Sur, Oaxaca. Does it represent a base for plant resources management and conservation?
}

\author{
Azucena de Lourdes Luna-José and Beatriz Rendón Aguilar ${ }^{2 *}$
}

\begin{abstract}
Traditional classification systems represent cognitive processes of human cultures in the world. It synthesizes specific conceptions of nature, as well as cumulative learning, beliefs and customs that are part of a particular human community or society. Traditional knowledge has been analyzed from different viewpoints, one of which corresponds to the analysis of ethnoclassifications. In this work, a brief analysis of the botanical traditional knowledge among Zapotecs of the municipality of San Agustin Loxicha, Oaxaca was conducted. The purposes of this study were: a) to analyze the traditional ecological knowledge of local plant resources through the folk classification of both landscapes and plants and b) to determine the role that this knowledge has played in plant resource management and conservation. The study was developed in five communities of San Agustín Loxicha. From field trips, plant specimens were collected and showed to local people in order to get the Spanish or Zapotec names; through interviews with local people, we obtained names and identified classification categories of plants, vegetation units, and soil types. We found a logic structure in Zapotec plant names, based on linguistic terms, as well as morphological and ecological caracteristics. We followed the classification principles proposed by Berlin [6] in order to build a hierarchical structure of life forms, names and other characteristics mentioned by people. We recorded 757 plant names. Most of them (67\%) have an equivalent Zapotec name and the remaining $33 \%$ had mixed names with Zapotec and Spanish terms. Plants were categorized as native plants, plants introduced in pre-Hispanic times, or plants introduced later. All of them are grouped in a hierarchical classification, which include life form, generic, specific, and varietal categories. Monotypic and polytypic names are used to further classify plants. This holistic classification system plays an important role for local people in many aspects: it helps to organize and make sense of the diversity, to understand the interrelation among plants-soil-vegetation and to classify their physical space since they relate plants with a particular vegetation unit and a kind of soil. The locals also make a rational use of these elements, because they know which crops can grow in any vegetation unit, or which places are indicated to recollect plants. These aspects are interconnected and could be fundamental for a rational use and management of plant resources.
\end{abstract}

Keywords: Traditional ecological knowledge, Ethnoclassification, Zapotecs, San Agustín Loxicha, Ethnobotany

\footnotetext{
* Correspondence: bra@xanum.uma.mx

²Departamento de Biología, Universidad Autónoma Metropolitana, Avenida

San Rafael Atlixco \# 186, Col, Vicentina, C.P. 09340, México, D.F., Mexico

Full list of author information is available at the end of the article
} 


\section{Background}

Traditional knowledge of indigenous or local people involves specific perceptions, beliefs and customs about natural environments [1,2]. Traditional knowledge is constructed by the close interaction between people and their environment through the daily use and management of natural resources and productive processes. It supports the subsistence activities of those groups that directly depend on the resource base [3,4]. Knowledge comprises the ways in which people categorize, code, process and impute meaning to their experience. These processes are based on an existing conceptual framework and are affected by the skills, interests, experiences, preferences, resources and patterns of social interactions that are characteristic of any particular group of individuals [5]. In this sense, traditional knowledge is the result of complex processes concerning social, cultural, institutional and ecological factors.

Traditional systems of classification or ethnoclassifications are expressions of traditional knowledge [6,7]. Knowledge generated through daily life interactions with plants and animals, as well as physical elements like climate and soil, is structured and integrated in different ways [8-10]. Many authors have analyzed the nature of these folk systems in terms of how they are structured [11]. Whereas Berlin and his collaborators argue that these systems follow a hierarchic and inclusive system, based mainly on distinctiveness or salience, for others, utilitarian features are the base of them; even more, some argue that in certain traditional cultures there are only proto classifications $[8,9,12,13]$.

In Mexico, traditional folk systems of classification have been analyzed since the 1970's, but few of them have been published. Some outstanding studies are those on ethnomycology among the Purépecha of Michoacán [14]; traditional nomenclature of plants, animals, soil, climate among Huaves of Oaxaca [15]; ecological ethnoclassification of the Chinantec and Mixe people of Oaxaca [16]; botanical nomenclature and structure of plant and animal classification of the Totonacos of Veracruz [5]; traditional classification and nomenclature of columnar and globular cacti among the Mixtec of Oaxaca [17], and a general analysis of classification in Maya culture [18]. The absence of these kinds of studies is paradoxical due to the high diversity of ethnic groups in Mexico that preserve local and ancestral traditions and customs.

\section{Zapotec ethnoclassification}

Zapotecs live in four geographic areas of Oaxaca, the Central Valley, the Itsmo, the Northern Sierra and the Southern Sierra [19]. Although the Zapotec represent the third most numerous ethnic group in Mexico, including $8 \%$ of the national ethnic speakers in the nation [19-21] and are one of the most important cultures within Mesoamerican civilizations [22], there are few studies analyzing Zapotec traditional classification systems.

In the middle of the XVI century, Fray Juan de Córdova described and analyzed the names of animals and plants used by Zapotecs in the Valley of Oaxaca [23]. According to him, Zapotecs classify animals based on locomotion (e.g., walk, fly), habitat, size, behavior and their similarities with other organisms. For example, máni péche include ferocious animals (jaguar, ocelote), while máni péla refer to animals without legs (snakes, worms). The animal names in Zapotec began with the word pe(be) o pi(bi), to indicate that they had a vital force that lead them to move. Plant classification was based on their usefulness, flavor and similarities with other plants. Messer [24] described the traditional plant classification among the Zapotec of Mitla, in the Central Valleys. She recorded five life forms, one of them corresponding to maize. Messer also showed how Zapotec terms refer to the plant growth stages and soil types where they grow. Brown and Chase [25] focused on Zapotec animal classification, among the people of Juchitán. In a similar way, the Zapotec of Santiago Xanica [26], identified and distinguished differences between mammals, birds and insects. Hunn and Acuca [27] developed a comparative analysis of Zapotec vocabulary used in present-day San Juan Mixtepec versus that reported in XVI century by Fray Juan de Córdova. Hunn later analyzed other aspects of Zapotec classification in the same locality [22]. While the modern Zapotec classification system includes 653 plant categories at a terminal level, more than 310 animals and 38 fungi, Córdova documented 309 plants, 290 animals, and 8 fungi. There are many patterns shared by both classifications, a comparision at life-form level shows these similarities (Table 1).

The present study was conducted in the Zapotec municipality of San Agustín Loxicha, Pochutla district, in the Sierra Sur of Oaxaca, within the 129 Terrestrial Priority Region of Mexico, [28]. Zapotecs of this region depend on agriculture and gathering of forest products for their subsistence. In consequence, their interaction with nature in daily life has allowed the construction of knowledge about plant resources and a relative distinction of nature's discontinuities, which are reflected in the existence of a traditional plant classification, as indicated in previous studies in this region [29-36]. The purposes of this study were a) to describe the traditional ecological knowledge of local resources through the folk classification of landscape and plants and b) to determine the role that this knowledge has played in plant resource management and conservation. 
Table 1 Comparison of Life-forms recognized among five Zapotec communities of Oaxaca

\begin{tabular}{|c|c|c|c|c|c|}
\hline $\begin{array}{l}\text { Biological } \\
\text { form }\end{array}$ & $\begin{array}{l}\text { Trinidad } \\
\text { Buenavista }\end{array}$ & $\begin{array}{l}\text { Santiago } \\
\text { Xanicaa }^{1}\end{array}$ & $\begin{array}{l}\text { San Juan } \\
\text { Mixtepec }^{2}\end{array}$ & Mitla $^{3}$ & $\begin{array}{l}\text { Valles } \\
\text { Centrales }\end{array}$ \\
\hline $\begin{array}{l}\text { Trees and } \\
\text { shrubs }\end{array}$ & Ya'a & Yak & Yàg & Yahg & Yága \\
\hline $\begin{array}{l}\text { Climbs and } \\
\text { lianas }\end{array}$ & Lús & & $\mathrm{lbÈ}$ & Behúk & \\
\hline Herbs & La'a bixhs & Quiish & Guizh & $K^{W} a n$ & Quijxi \\
\hline $\begin{array}{l}\text { Grasses } \\
\text { (zacate) }\end{array}$ & Ixhs & & & Gishi & \\
\hline Magueyes & Dob,Yes & Toob & Dòb & & Toba \\
\hline Canegrasses & Yií & Shiil & & & \\
\hline Palms & Yiin & & & & \\
\hline Quelites & Yed * & & & & \\
\hline Bromeliads & Bla,bla lo ya & & & & \\
\hline Orchids & $\begin{array}{l}\text { Goo lad ya, } \\
\text { Xhil }\end{array}$ & & & & \\
\hline Ferns & Yoóh & & & & \\
\hline $\begin{array}{l}\text { Mosses, } \\
\text { hepatics, } \\
\text { lichens }\end{array}$ & Mbaxhs & & & & \\
\hline Flowers & lyé * & Kiée & Guièe & & Guije \\
\hline Fruits & & $\begin{array}{l}\text { Nguith } \\
\text { shlea }\end{array}$ & & & \\
\hline Mushrooms & & Meí & & & \\
\hline Nopales & & Blaa & & & \\
\hline $\begin{array}{l}\text { Tuberous } \\
\text { roots and } \\
\text { corms }\end{array}$ & & Kú & & & Còo \\
\hline Leaves & & & Blâg & & \\
\hline Medicinal herbs & & & Ncuàan & & Nocuana \\
\hline Beans & & & Bziàa & & \\
\hline Corns & & & & Yähl & \\
\hline
\end{tabular}

*Terms applied to groups of plants that have utilitarian value in the communities of San Agustín Loxicha, while in other communities of Oaxaca are reported as life-forms.

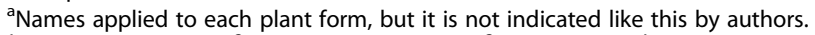
${ }^{1}$ Cruz and Cruz, 1992; ${ }^{2}$ Hunn and Acuta, 2001; ${ }^{3}$ Messer, 1978; ${ }^{4}$ Marcus and Flannery, 2001.

\section{Methods}

\section{Study site}

The municipality of San Agustin Loxicha (Figure 1), is located at the SW of Oaxaca city $\left(16^{\circ} 01^{\prime} 55^{\prime \prime} \mathrm{N}\right.$ and $096^{\circ}$ $\left.37^{\prime} 01^{\prime \prime} \mathrm{W}\right)$, in one of the troubled branches of the Sierra Madre del Sur. It occupies a total area of $389.1 \mathrm{~km}^{2}$. The administrative centre of the municipality is located at an altitude of 1,820 ma.s.l., though sparse settlements are found at lower and higher altitudes. The distance between San Agustin Loxicha and Oaxaca City is $180 \mathrm{~km}$ [37] Average temperature in San Agustin Loxicha is $16^{\circ} \mathrm{C}$, with a minimum of $-3^{\circ} \mathrm{C}$ and a maximum of $2^{\circ} \mathrm{C}$ throughout the year at different elevations [27]. Annual rainfall corresponds to $1,500 \mathrm{~mm}$ [38]. Soils are typically Regosol eutric and Cambisol distric, ortic and cromic with a fine texture. Rocks are metamorphic and date from the Precambrian period [39]. Vegetation varies in an altitudinal gradient from 330 to 2,250 masl [28,37], and seven vegetation units [31] are found: pine forest, pine-oak forest, oak forest, cloud forest, evergreen forest, tropical subdeciduous forest, and tropical deciduous forest [29-32].

Recent research indicates that Zapotecs in this region were established four centruries ago by people from Miahuatlan, specifically from San Agustin Mixtepec, who moved to the south [40]. Even when they exhibit a positive population growth rate, from the last three decades to present, a high rate of emigration (mostly seasonal migration) has been observed, with the consequential abandonment of their lands.

In 2005 (INEGI 2005), the municipality of San Agustin Loxicha had 17,823 people living in 8 municipal agencies and 61 colonies or barrios. Only $6 \%$ of the people live in two of the most important communities: San Agustín Loxicha and Tierra Blanca. Almost 80\% (14125) of the people speak Zapotec, and $77 \%$ of them are bilingual, while the rest are only Zapotec speakers.

At higher elevations, the main activity is coffee cultivation in traditional systems in which coffee is intercropped with other plants like avocado (Persea americana Mill) (Lauraceae), guava (Psidium guajava L.) (Myrtaceae) and mango (Mangifera indica L.) (Anacardiaceae) under the cover of native tree species. Maize cultivation is also practiced in a traditional system, managing different native varieties of maize (Zea mays L.) (Poaceae), bean (Phaseolus vulgaris L.) (Fabaceae), and squashes (Cucurbita spp.) (Cucurbitaceae); farmers also promote or tolerate other edible non-crop species like chepil (Crotalaria longirostrata Hook \& Arn.) (Fabaceae) and hierbamora (Solanum nigrum L.) (Solanaceae) within their maize fields. At lower elevations coffee is intercropped with guanabana (Annona muricata L.) (Annonaceae), several citrus species (Citrus spp.) (Rutaceae) and sugarcane (Saccharum officinarum L.) (Poaceae). Finally, at the lowest altitude, farmers cultivate maize in the traditional milpa system intercropping it with commercial species like Jamaica Roselle (Hibiscus sabdariffa L.) (Malvaceae) and watermelon (Cucumis melo L.) (Cucurbitaceae) in addition to various edible herbs $[33,34,41]$. Forest management is another important activity because different products are obtained for local or regional consumption [36].

The municipality of San Agustin Loxicha is located within the 129 Terrestrial Priority Region of Mexico, named Sierra Sur y Costa de Oaxaca, which is defined as a highly preserved area in terms of plant cover [28]. It is an area unexplored in terms of ethnobiological and 


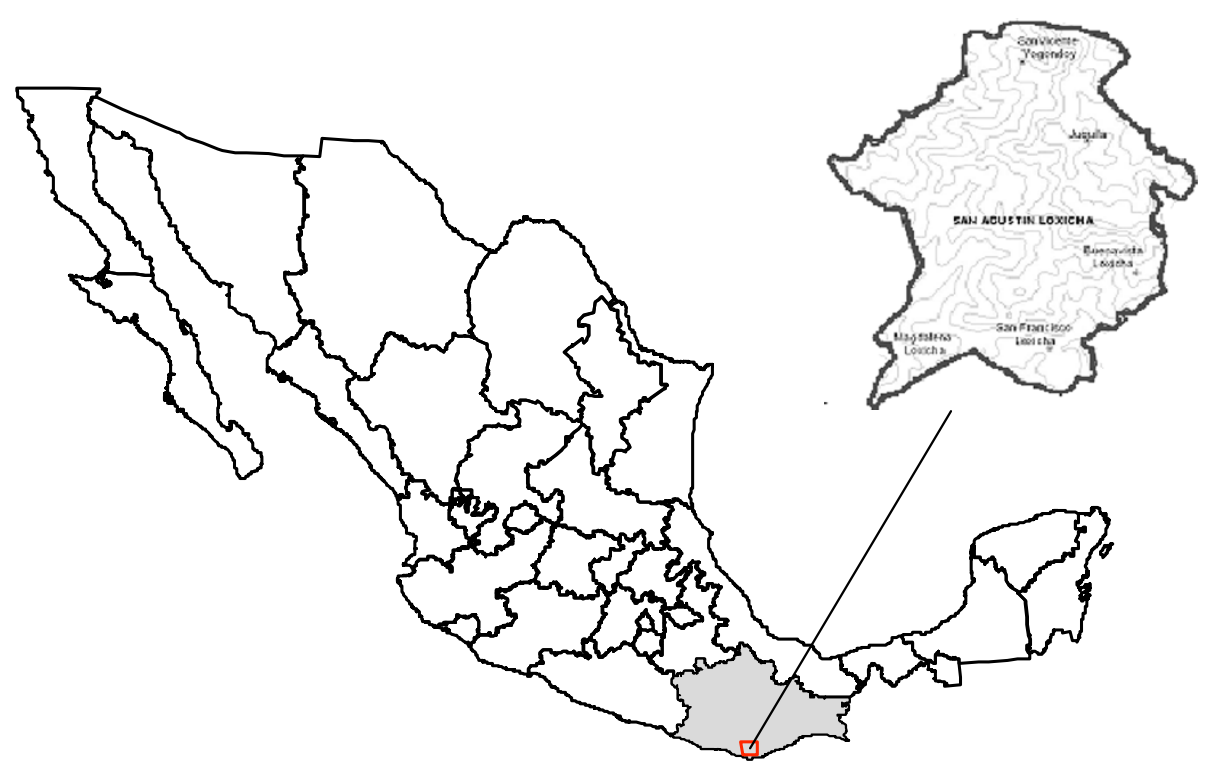

Figure 1 Location of the San Agustín Loxicha municipality. (Elaborated by: Gilberto Hernández C.). In this map, the location of the state of Oaxaca and the study area within it, is indicated.

ecological studies, until the last ten years, when few studies have been developed [29-36].

\section{Fieldwork}

\section{Selection of communities}

Fieldwork was conducted during 2004 and 2005 in five communities of San Agustin Loxicha: Juquilita, Magdalena Loxicha, San Francisco Loxicha, Trinidad Buenavista, and San Vicente Yogondoy (Figure 1; Table 2). To select the communities where fieldwork would be conducted, we considered two criteria determined in a previous study [29,35]: that communities were distributed throughout the whole altitudinal interval in order to represent the floristic diversity present in the entire municipality, and communities had a minimum of 300 inhabitants. Data from the population census was used to select these communities [42]. The project was presented to the local authorities of the selected communities in order to ask their permission, and to facilitate the execution of the research. They were completely accorded with our presence. In some cases, they called the people of the community to an assembly in order to introduce us to them. Part of the successful welcome to the communities was due to the fact that the main author is a

Table 2 Geographic location, physical and economic characteristics of the five communities studied in the municipality of San Agustín Loxcicha, Sierra Madre del Sur, Oaxaca (PF, pine forest; POF, pine-oak forest; OF, oak forest; SDF, subdeciduous forest; CMF, cloudy mountain forest; EGF, evergreen forest; DF, deciduous forest)

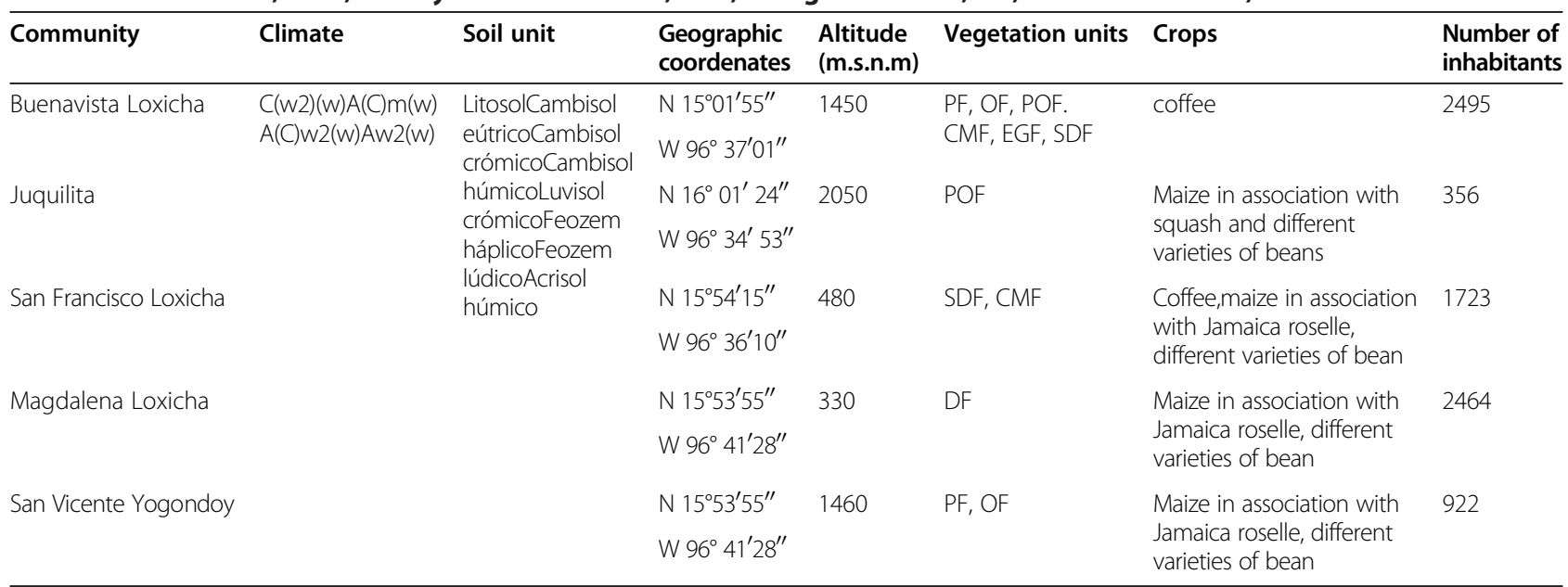


member of one of the communities and speaks Zapotec. In the communities of San Francisco Loxicha and Juquilita the local authorities faciliated household visits in order to conduct the interviews.

\section{Interviews}

We selected 20 people from each community, based on the facility they offered to the interview. We maintained the same proportion of men and women. Since according to Berlin [12] six year old children recognize generic plant elements, we included in our study the perception of all members of the community, selecting people from 8 to 80 years old [43].

We contacted people in their houses, in the streets, or in the small markets, and explained to them the objectives of our research and told them that the interview lasted between 20 and 30 minutes. In most cases, people agreed to participate. In many cases, we conducted the interviews on casual walks to the milpa, or the coffee plantations, and collected plants with them. When we had doubts about a plant identity, we asked them to collect it, in order to determine if this species was different but had the same name.

The questionnaire consisted of four questions: what are the Zapotec and/or Spanish names of the plants that are gathered or cultivated; what are the uses of each plant mentioned; what is the recognized life form; and where and how are the habitats where the plant species occurs. During the interview, we asked people to describe plants, in order to know what species they were talking about. It is important to indicate that previous plant vouchers had been collected, as well as an existing list of local names (Zapotec and/or Spanish), from field studies developed in this and two other municipalities of this region during 2002-2004 (Candelaria Loxicha and Pluma Hidalgo). Most of them corresponded to floristic and structure characterization of different plant communities (pine-oak-subdecidous forest association, subdeciduous forest, cloudy forest). The others consisted of a characterization of floristic composition of traditional coffee systems, and a study of forest resources [30-33,36]. In all cases, Zapotec or Spanish names of plant species were recorder and voucher specimens were collected. In this study, we verified syntaxys, including the prefix used for each life form. In those cases where prefix was not incorporated, or plant species only had a Spanish name, we asked people to identify which life form that species belonged to. The zapotec names were reviewed by an elementary school teacher.

We also asked them about what characteristics they use to classify soil and vegetation types. In the case of soil, only color and texture were considered for classification. In the case of vegetation types, they considered plant cover, tree size, plant species, altitude, and soil characteristics.

With the information gathered from the interviewers, we followed Berlin's taxa system, based specifically on plant names, as well as morphological and ecological attributes. The linguistic component was a factor in grouping plant elements. We tried to establish nomenclatural relationships, taking into account most of the aspects discussed by Berlin, like mono or polytypic, primary, secondary, productive or unproductive names [12]. For generic taxa, we considered the lexical terms applied to each plant species. We also verified if people grouped them in the same term, asking them "if plants are sisters or if they are almost the same", this concept was frequently used by the locals themselves. This identifying process was also used with specific/varietal names: we "elaborate" with them the classification of those species from the life form to the last category they considered. In the case of polytypic names, we included them in those cases when one Zapotec name was applied to different Latin species. In the case of productive names, we considered them when Zapotec terms describe in an explicit way some plant attributes whereas unproductive names correspond to Zapotec terms that do not correspond with any of them.

Since plant names, as well as the logic followed to group them, were documented in previous studies to the present $[30-33,36]$ we found that this classification was consistent and represented the cognitive processes that people have organized through generations [11].

Voucher specimens were collected in the study area during field trips and deposited in the herbariums of Universidad Autónoma Metropolitana (Ramón Riva y Nava -Esparza) and the Universidad Nacional Autónoma de México (MEXU).

\section{Results}

\section{Landscape classification}

Zapotecs use the term isyo for naming general environmental units; for instance, they use the term isyo bixhs' for referring to dry lands and isyo nayee for referring to relatively more humid land with green plant cover. They recognize that temperature and humidity influence plant distribution and that there are some plants growing exclusively in hot areas (isyo nasú or isyo nacee) and others growing in colder and wetter environments (isyo nal). Zapotecs also use the term wán for naming all forest or vegetation types, but use particular epithets for referring to specific types (Figure 2).

Wán applies to plant components and based on physiognomy and disturbance level, they are further grouped into three Zapotec categories: wán nosa (mixed vegetation), includes cloudy mountain, evergreen, subdeciduous and deciduous forest, it's characterized by a 


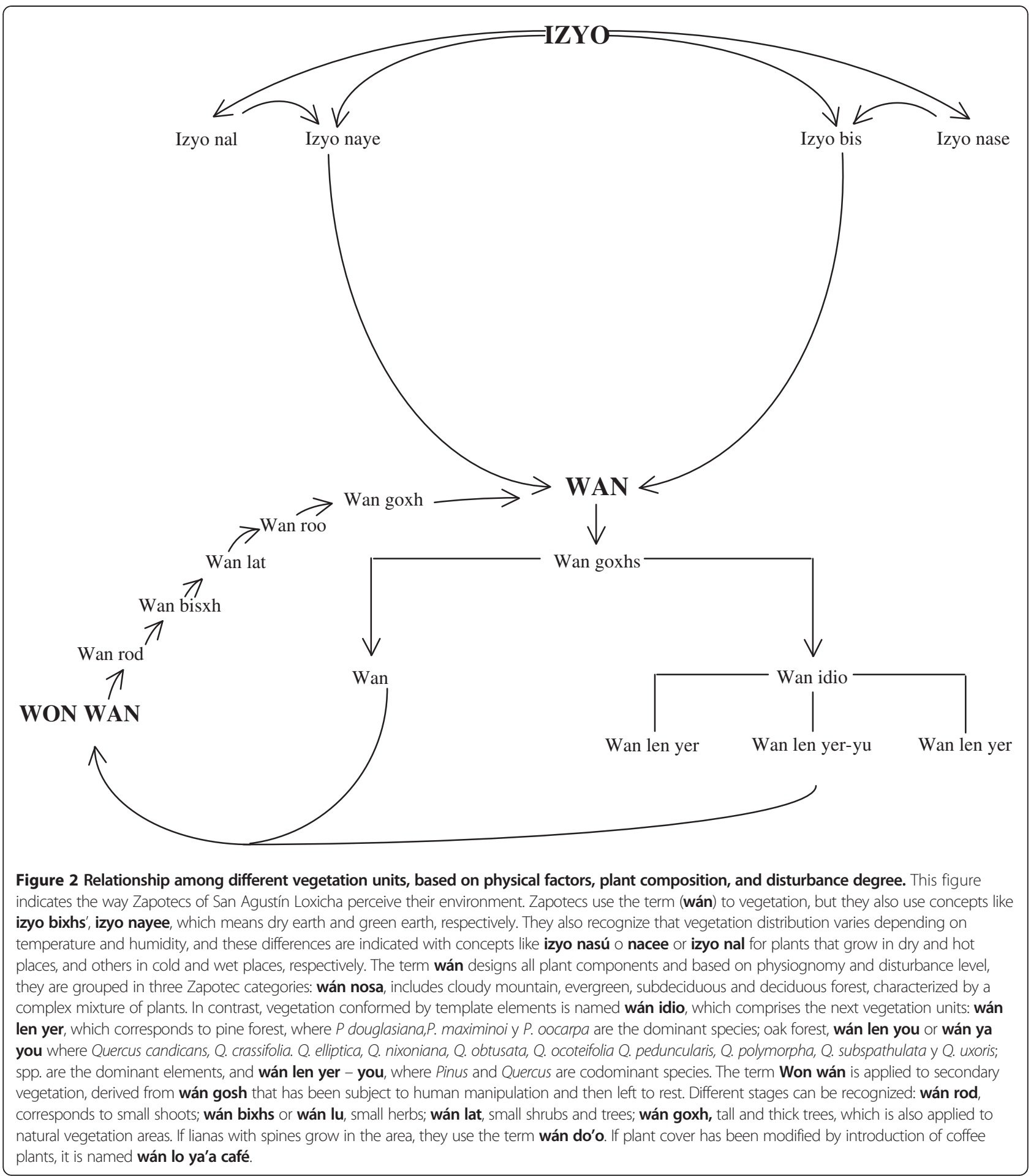

complex mixture of plants. The Zapotec do not use a specific term for each of these vegetation units. Vegetation conformed by temperate elements is named wán idio (mountain vegetation) and includes the following vegetation: wán len yer (pine forest), where $P$ douglasiana Martínez, P. maximinoi H.E. Moore y P. oocarpa
Schiede \& Schltdl. are the dominant species; wán len you or wán ya you (oak forest), where Quercus candicans Née, Q. crassifolia Humb. \& Bonpl., Q. elliptica Née, Q. nixoniana S. Valencia \& Lozada-Pérez, Q. obtusata Bonpl., Q. ocoteifolia A. Camus, Q. peduncularis Née, Q. polymorpha A. DC., Q. subspathulata Trel., and 
Q. uxoris McVaugh are the dominant elements, and wán len yer-you (pine-oak forest), where Pinus and Quercus are codominant species.

The term won wán is applied to secondary vegetation derived from wán gosh, that has been removed, and then left to rest. Different stages can be recognized: wán rod, corresponds to small shoots; wán bis or wán lud (small vegetation), small herbs; wán lat (thin vegetation), small shrubs and trees; wán goxh (old vegetation), tall and thick trees, which is also applied to natural vegetation areas. If lianas with spines grow in the area, they use the term wán do'o. If plant cover has been modified by introduction of coffee plants, it is named wán lo ya'a café.

Zapotecs interviewed said that soil type also influences the landscape form. In general, soils present in the community are diverse. According to literature and soil maps $[44,45]$, there are three main soil types: luvisol, regosol and dystric, crhomic and orthic cambisol. Traditional classification is based on texture and color. Yü nagat (black soil) corresponds to a fertile soil with a large accumulation of organic material where vegetation is abundant and/or productive and can be generally found in the pine forest. Yü nguin (sticky soil) is found mostly in the jungle, it is mixed with pine leaves and used to build adobe homes and braceros (to boil food). The sands around the rivers are known as yü yuxhs (sandy soil), and the white soils found in the lower regions are called yü nequis (white soil). Queda (rock) is a rocky soil with poor plant cover. Soil classification is also related to the crops that grow better on them. Thus, maize grows better in black, white and rocky soil, while coffee plantations are located mainly in clayish soils with high accumulation of organic matter (Table 3).

\section{Ethnobotanical system of classification}

We recorded 757 plant names. Most of them (67\%) have an equivalent Zapotec name and the remaining 33\% had mixed names with Zapotec and Spanish terms. Plant species named and classified by Zapotecs are mainly native, but some of them are species introduced to the region in pre-Hispanic or later times but play a basic role within the culture because they are part of their daily diet.
Plants are named and grouped in a hierarchic system based on ecological and morphological characteristics. People recognize plants from the tropics, the temperate areas, or those that are found in specific sites (e.g., pines and oaks are mainly distributed in temperate areas, so their name is related with their ecological distribution: wán len yer is pine forest and wán len you is oak forest).

To classify plants in the different life forms, Zapotecs include morphological and physiological characteristics as well as anatomic structures or tastes. They differentiate tubers (goo) from roots (loxhs), or colorful petals (iyé), from inflorescences like spadixes and spikes (dob). Other structures are stems (tronc), branches (cosdxod), barks (Xxäb), leaves (Lla'a), fruits (ngud), and seeds (mbis). For example, many epiphytes have the prefix goo (e.g., goo biuxhs (Bomarea edulis (Tussac) Herb) (Astroemeriaceae); goo xhil (Dioscorea mexicana Scheidw.) (Dioscoreaceae), which make reference to the presence of tuber; in the case of agaves, the term dob makes reference to the large inflorescence (e.g., ya'a dob bhied (Agave spp.) (Agavaceae). In another example, plants with underground stems (like some cycads) are classified in the same way as orchids and dioscorids, or other plants that have tuber. Goo ya'a corresponds to Manihot sculenta Crantz (Euphorbiaceae), ya'a goo xhil to Ceratozamia aff. longifolia Miq. (Zamiaceae), and goo malang to Colocasia esculenta (L.) Schoot (Araceae), while loxhs corresponds to the rest of the plants that exhibit a normal root system (Figure 3).

In this context, the semantic structure of terms used for the 757 plants exhibit a regular pattern highly related to morphological, anatomical, physiological and ecological attributes, which allows us to group plants in a hierarchical structure. Zapotecs clearly differentiate many fungi, identified as mbey, from animals, grouped under ma'a, and from plants, known as wán (vegetation). This term is also applied to the vegetation, which means that unlike individual beings, the plants are perceived as a whole and integrated into different systems (e.g., primary or secondary vegetation).

In the second level of this hierarchical classification, we found that people always group plants in one of the seven recognized life forms. In most of the cases, life form is an explicit term of the name applied to each

Table 3 Soil classification and its relation to climate, vegetation and human activities developed on them

\begin{tabular}{|c|c|c|c|c|}
\hline Soil & Climate & Vegetation & Crop & Another activities \\
\hline Yü nagat (black soil, humus) & Izyo nal (template) & $\begin{array}{l}\text { wán len yer (Pine forest), Wán len } \\
\text { yer-yuo (Pine-oak forest), Wán len } \\
\text { yuo(Oak forest) }\end{array}$ & Maize with squash and beans & Forest wood \\
\hline Yü ngüin (clayish soil) & & $\begin{array}{l}\text { wán (Cloud mountain forest, evergreen } \\
\text { forest y subdeciduous forest) }\end{array}$ & Coffee & Coffee system \\
\hline $\begin{array}{l}\text { Yü yuxhs (Sandy soil with small } \\
\text { rocks), Yu nequis (White soil) }\end{array}$ & $\begin{array}{l}\text { Izyo nase (template/ } \\
\text { tropical, humid) }\end{array}$ & $\begin{array}{l}\text { wán (Cloud mountain forest, and } \\
\text { subdeciduous forest) }\end{array}$ & $\begin{array}{l}\text { Coffee, maize with squash and } \\
\text { beans }\end{array}$ & \\
\hline $\begin{array}{l}\text { Yü nequis (White soil), Queda } \\
\text { (rocky soil, without plant cover) }\end{array}$ & Izyo bixhs (hot, dry) & wán (deciduous dry forest) & $\begin{array}{l}\text { Maize in association with Jamaica } \\
\text { roselle, and Sollamiche palms }\end{array}$ & Livestock \\
\hline
\end{tabular}




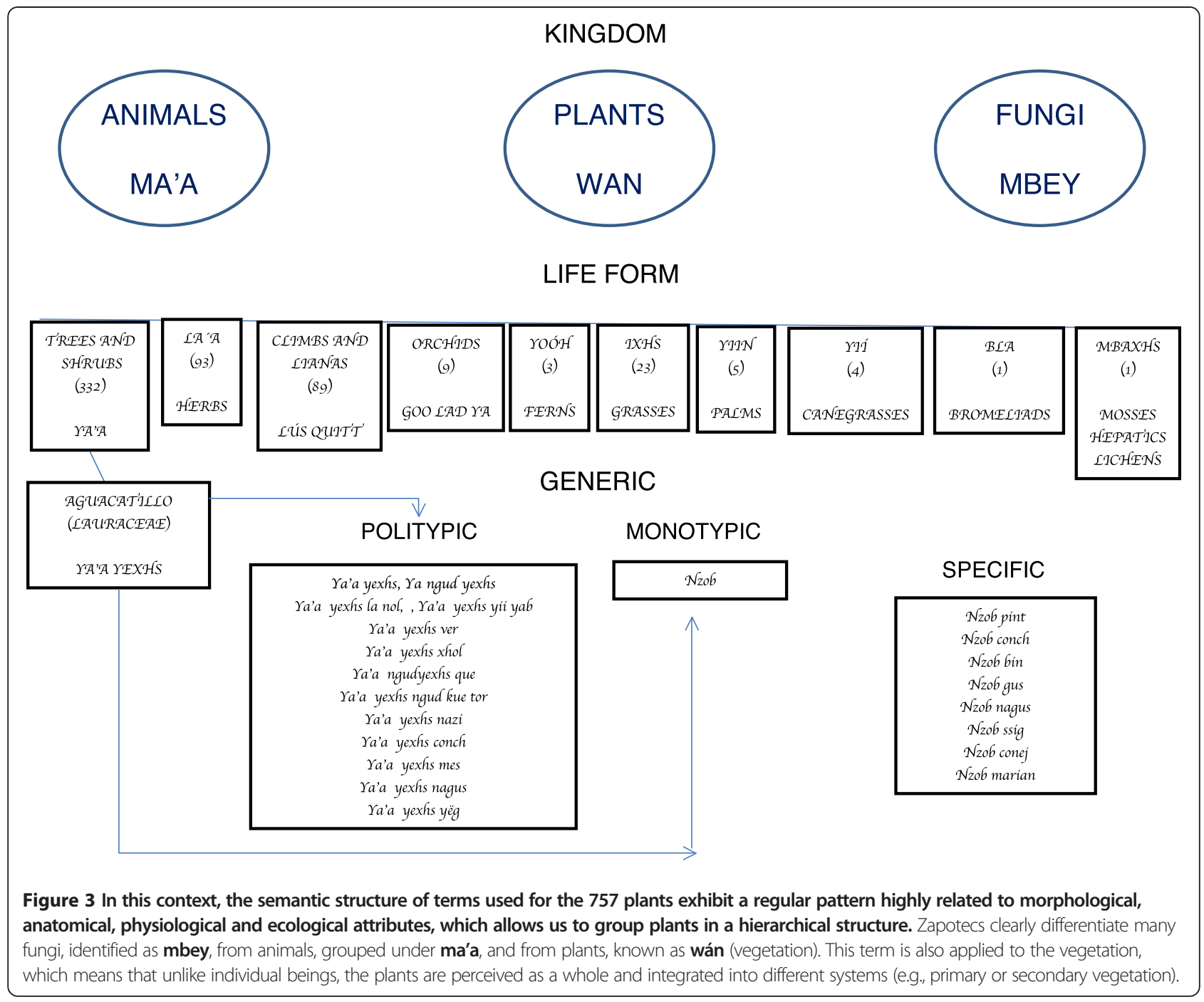

species: ya'a, is applied to trees and shrubs. In the nomenclature, this corresponds to the first term of the name (e.g. ya'a tii, Guazuma ulmifolia Lam. (Sterculiaceae), and ya'a treen, Croton draco Schltdl \& Cham.) (Euphorbiaceae). In some cases, the term ya'a is replaced by another enhancing a particular characteristic. Nevertheless, the plant is recognized by the life form. For example, banana is considered as a ya'a but people name it as bdó, because the main attribute is the fruit. In other cases, it is possible that plants introduced in recent times, weren't incorporated into the classification system. Lús, is a term used for climbs and lianas. Some plants are included in this group based on their appearance. Guarea sp. (lús quitt) (Meliaceae) is a decumbent shrub, but it is included in this group because its branches extend and the thin stems have the resistance and ease to bend like vines to create an arch. Baccharis trinervis Pers. (lús cunic) (Asteraceae) is a branch-like weed/herb whose branches on occasion extend in the form of a guide. La'a bixhs is used to name herbs, even though this term is also applied to the tree and shrub leaves. Ggoo lad ya is used to identify orchids because it means "camote that grows on the tree". Goo can also be applied as a generic term to name the corms, bulbs and tuberous roots; yoóh, means ferns; ixhs, grasses; yiin, palms; yií, canegrasses; dob, agaves; bla, bromeliads; mbaxhs, mosses, hepatics and lichens. We found that people sometimes grouped colorful flowers and "quelites" in separate categories (iyé and yed, respectively). Nevertheless, all of them are grouped in some of the previous categories, mostly ya'a, la'a bixhs and lús (Figure 3).

In the next level, the particular name given to each species is indicated as a generic term. In the case of monotypic names, diverse combinations of terms were found: simple terms in Zapotec (11 species; i.e., fdión, ngüti, nij); simple terms with a light modification since the words are borrowed from Spanish, generally with the elimination of the last letter (13 species, i.e., mirt, mostrnz, manzan); species that completely maintain 
their Spanish name (111 species, i.e., bambú, sávila, cedrón, eucalipto, hierba de pollo); Zapotec prefix (generally corresponds to the life form) and Spanish suffix (53 species, i.e., ixhs limún, lús granad, la’a cancer, ya'a mang, iyé San José) and Zapotec prefix and suffix (201 species, i.e., la'a gaxhs, la'a ya mbesh, ixhs mbad, lús quitt, ya'a ngud khin, ya'a ngüid, iyé mengo, yed ñia) (Figure 3).

We obtained 377 polytypic names, which correspond to 88 groups. In most cases they are species of different families, although in the case of the members of Melastomataceae, Fagaceae, Mimosaceae and Lauraceae, the names corresponds to the same family, but different genus or species. An example of this generic polytypic is represented by species of the Lauraceae family. People include all species, corresponding to different genus, in the generic term ya'a yexhs. Nevertheless, the morphologic attributes used to include them are the form of the trunk and the leaves, as well as the characteristic odor of the leaves (Table 4).

We found 23 primary productive names, which are chosen according to some characteristic of the plant, as in the case of la'a arla, leaf (la'a) bitter (arla). The name implies that the leaf is bitter. The non-productive names do not have any relation with the plant, as in the case of the "ear of lion", which morphologically does not have any similarity with this feature. Of these last cases only 15 (2\%) were found.

In the case of some taxonomic groups that are not often used, i.e. mosses, lichens and hepatics, a generic category exists that is based on the growth habit. Mosses and hepatics that grow in the superficial part of the

Table 4 Generic polytipic taxa represented by different species of Lauraceae

\begin{tabular}{|c|c|c|}
\hline Zapotec name & Spanish name & Scientific name \\
\hline $\begin{array}{l}\text { Ya'a yexhs, ya ngud } \\
\text { yexhs }\end{array}$ & Aguacate & Persea americana Mill. \\
\hline $\begin{array}{l}\text { Ya'a yexhs la nol, } \\
\text { ya'a yexhs yii yab }\end{array}$ & & $\begin{array}{l}\text { Nectandra cuspidata Nees \& } \\
\text { Mart. }\end{array}$ \\
\hline Ya'a yexhs ver & Aguacatillo & Ocotea atacta Lorea-Hern. \\
\hline Ya'a yexhs xhol & $\begin{array}{l}\text { Aguacatillo, palo } \\
\text { guatoso }\end{array}$ & $\begin{array}{l}\text { Persea aff. donnell-smithii } \\
\text { Mez }\end{array}$ \\
\hline $\begin{array}{l}\text { Ya'a ngudyexhs } \\
\text { que }\end{array}$ & Aguacate piedra & Persea nubigena L.O. Williams \\
\hline $\begin{array}{l}\text { Ya'a yexhs ngud } \\
\text { kue tor }\end{array}$ & Aguacate de toro & Persea sp. \\
\hline Ya'a yexhs nazi & Aguacate oloroso & Persea sp. \\
\hline Ya'a yexhs conch & & Persea sp. \\
\hline Ya'a yexhs mes & & Persea sp. \\
\hline Ya'a yexhs nagus & & Persea sp. \\
\hline Ya'a yexhs yëg & & Persea sp. \\
\hline
\end{tabular}

In this case, the generic term is a'a yexhs. ground are called mbaxs lad ble. Lichens that hang off the branches of trees are labeled mbaxs lo ya'a, and those that grow on the branches of coffee plants are mbaxs lo ya'a cafe.

In some cases, Zapotecs group plants that show marked perceptual similarities among the members, but they belong to different orders, or even more, to different divisions. For example, palms are subdivided in three generic taxa, and cycads are included in one of these. Thus, arborescent palms (Arecaceae) are grouped in the taxon ya'a gaá. Shrubby palms are divided in another two taxa, ya'a xhil (Chamaedorea aff. Elegans Mart.), which also included the cycad Ceratozamia aff. longifolia Miq. (named as ya'a xhil goo), the palm ya'a yiín (Cryosophila nana (Kunth) Blume ex Salomon), and the arborescent fern ya'a yoóh xhil (Cyathea costaricensis (Mett. ex Kuhn) Domin). In the case of ya'a yiín, the recognized subdivision within the shrubby palms is due to their present distribution in the lower tropical regions.

Another example is the generic yeg that means pumpkin, which includes species of two families: Cucurbitaceae and Asclepiadaceae. Pumpkins (Cucurbita spp.) are named as yeg, while yeto, an Asclepiadaceae of the genus Gonolobus, is named yeg na, possibly due to the fruit appearance and life-form.

At the varietal level, in all cases, Zapotecs group the varieties of a species, a process similar to the infraspecific occidental classification, but also species belonging to the same genus. We recorded 137 species belonging to 36 varietal taxa, among which chile, pumpkin, bean, corn, grasses, banana, and cuiles are the most representative. One example corresponds to maize, which different names correspond to different varieties (Table 5, Figure 3). Most of the species that are located in this specific/varietal category correspond to cultivated plants.

\section{Discussion}

Landscape and soil classifications

Plant communities' classification is similar in some aspects to scientific science. In ecology, they are classified in terms

Table 5 Varietal taxa recognized for different native varieties of Zea mays. Generic term is Nzob

\begin{tabular}{ll}
\hline Zapotec name & Native variety \\
\hline Nzob pint & Pinto \\
Nzob conch & Azul \\
Nzob bín & Tepezentle \\
Nzob gus & Amarillo \\
Nzob nagus & Tablita, normal \\
Nzob sig & Delgado \\
Nzob conej & Conejo \\
Nzob marian & Magallano \\
\hline
\end{tabular}


of their physiognomy (e.g., dominant species), composition or geomorphic features. In the present study, we found that Zapotecs classify landscape using physiognomy, composition and habitat criteria (altitude and climate). This aspect has been reported previously for other ethnic groups [16,46-48]. The recognition of these aspects is important because Zapotecs use them to establish different uses of plant communities: to limit their community, to obtain different products (plants or animals), to have places to rest and enjoy, to preserve some areas as a communal property. Nevertheless, plant communities are strongly related to the concept of earth, which in turn relates to the concept of soil. The earth determines what kind of vegetation can grow and its characteristics. The terms isyo nayee (green earth), and isyo bixhs' (dry earth), correspond to the first level from which they recognize or determine which plant components can be found. From here, the next perceptual associations identify the kind of crops and plants of the natural vegetation that can grow on the land (black soil grows coffee; sandy soils grow palms; red soils grow pine and oak forests), and indicate a deep and ancient knowledge that has played an important role not only in the Zapotec understanding of plants adaptive significance, but also in the integration of these soil-vegetation perceptions into their daily activities $[49,50]$.

\section{Ethnobotanical system of classification}

The Zapotecs recognize, name and classify not only those plants that are useful for them in a utilitarian context (i.e. medicine, food, firewood), but also those plants that do not have an immediate use. These are also important because some ecological or biological characteristic, like ecological dominance or some biological particularity (e.g., plants that grow in specific places), show and contribute to the integration of diverse biological and physical elements in the natural environment. Names of these species were reported in other papers by the same authors (e.g., Bursera simaruba (L.) Sarg. (Burseraceae), Hymenaea courbaril L. (Fabaceae), Myriocarpa longipes Liebm.) (Urticaceae) [35].

Zapotecs exhibit a deep traditional ecological knowledge in the Sierra Sur of Oaxaca in the sense that a fine classification exists, and also shows how they perceive their environment. Vascular plants, which include pteridophytes, gymnosperms and angiosperms, were classified with Zapotec terms, including life form, generic and in many cases, specific/varietal taxa. This classification shows a high correspondence with scientific terms and thus demonstrates the cultural, ecological, and economical importance of these plant elements. In the case of non-vascular plants, which include mosses, hepatics and lichens, they are grouped in Zapotec terms that include Linnean orders, families and species, making a very diffuse hierarchy for these organisms. Nevertheless, we cannot conclude that these plant elements have less importance to Zapotec culture, but rather are perceived in a different way by them. A comparative analysis with other studies, showed evidence that a traditional term corresponding to kingdom category is applied to some or all the non vascular elements. For example, among the purépechas [14] and the totonacos, a term exists that distinguishes mushrooms in a separate group [5] (although in the last ethnic group, there is no term assigned to the plants). These same finds have been recognized in other ethnic groups of Cameroon [51] and Venezuela [49]. Nevertheless, among the Wola, of New Guinea, there is no evidence of a term assigned to any element of the vegetable kingdom [46]. Martínez [50], comments that in Mesoamerican groups, a concept of plant does not exist. We believe that the idea of plant is strongly linked with vegetation or "monte" as other studies indicate $[23,26,52]$. Thus, this concept conforms a plant-vegetation duality, so it is more complex that the existence of a singular plant model.

Life form is a fundamental element in the traditional classifications since it reflects the distinction made between forms based on the visible morphology and ecological adaptations. There are different interpretations about what a "life form" is and which are the attributes that characterize this highly inclusive botanical category [10]. Nevertheless, there is a general agreement that they are recognized in different cultures. Different studies developed in Zapotec communities report among five to eight life forms [12,19,20,23,26,27] (Table 1). In all the cases, including this study, trees and shrubs are grouped in one category, possibly due to the fact that it includes the idea of wood and firewood. This is a similar pattern reported by Hunn [10] and discussed by Caballero and Cortés [18] and clearly indicates that life-forms are strongly linked to other aspects of Zapotec cosmovision, in this case with daily life activities and necessities of the people. More discussion must be made to define clue characteristics that must represent a life form within the indigenous perception, as Hunn [10] indicates. We also must consider Brown and Chase's appreciation [25] about the role that modernization has on traditional cultures, which in part, is reflected in an increasing number of life forms.

As Berlin [12] indicates, generic taxa are the most numerous. It is important to mention that the majority of the elements are monotypic, which shows that a high proportion of them correspond with scientific taxonomy. Previous studies in Zapotec communities did not analyze this category, so we do not have any point of comparison. Nevertheless, Mapes et al. [14], Aparicio y García [5], Caballero and Cortés [18], and López-Franco [21], reported a similar pattern and reinforced the observation that these taxa have high levels of correspondence with 
occidental taxonomy. At the same time, the low percentage of species with names borrowed from Spanish or Spanish names indicate that most of the plant elements have been used long time before the Spanish Conquest.

Finally, specific/varietal names correspond to frequently used species in the community. Such is the case of corn, beans, pumpkins, tomatoes and chiles, which denotes an intensive selection process under domestication. Other examples of this fine perception and classification have been reported with Manihot sculenta [38], and with many cacti species like Opuntia pilifera F.A.C. Weber [53], Stenocereous stellatus (Pfeifer) Riccob., S. queretaroensis (F.A.C. Weber) Buxb., S. pruinosus (Otto) F. Buxb., Escontria chiotilla (F.A.C. Weber) Rose, Polaskia chichipe (Gosselin) Backeb. and P. chende Gibson \& Horak [54].

\section{The role of traditional knowledge in plant resource management and conservation}

The site of study is located in one of the 125 Terrestrial Priority Regions proposed in 2000 by the National Comitée for Biodiversity Knowledge and Use (CONABIO). This region presents a wide plant cover, conformed by different types of vegetation, but an important presence of pine-oak forest, cloudy mountain forest, and tropical subdeciduous forest.

Human activities are comprised by a farming system that includes the management of different land use units like maize, fallow land, coffee forest gardens, homegardens and forest. The system integrates both subsistence and commodity production. Home-gardens, maize and fallow land are mainly used to produce food for self consumption while coffee forest gardens are used to generate cash income [55]. Coffee is cultivated under the canopy of natural or managed forest. The rest of the farm activities involve reduction of plant cover.

In this context, a high percentage of plants integrated to the folk systems are part of at least one of the farm systems, and they play specific roles within them: to shadow coffee shrubs, as an organic fertilizer in coffee systems and in some "milpa" areas as food, or medicine. Most of them are wild, so people must know where the plants exist, their phenology, abundance, and other traits, in order to get these resources. In this process, people make comparisons between plants, organize and classify them, and develop a holistic concept of each plant within the context of its environment. Many plants are favored over others, but all of them are important. Even when some plants are dangerous because they are toxic for humans or animals, they are considered in this holistic view [35]. This understanding of nature allows for the continued protection of natural resources even when they are subject to daily use.

The present study reinforced the findings analyzed by Toledo et al. [2], that highly preserved area in Mexico, in terms of biodiversity, are occupied by ethnic groups that make a rational use of natural resources.

\section{Conclusions}

In the context of Zapotec culture, this fine system of classification reflects the knowledge that the Zapotecs have inherited from their ancestors and the importance of knowing the existence and function of the elements that are part of their local environment. In the context of scientific science, this traditional ecological knowledge has contributed enormously to preserve plant cover of a wide area of this municipality, even when the communities have been established more than a century ago. This is a consequence of the different strategies that they have developed through generations: daily use of many plants for food, medicine, timber, etc.; the traditional management of their productive systems (milpa with policulture and coffee plantations with native plants). These strategies emerge from their necessity to rely on their ambient vegetation. Because they understand their situation better than foreign people, they try to make the best decision about how to manage a particular plant or a particular plant community. Through experimentation they decide where to sow a particular crop and try to avoid negative effects (soil erosion, bad crop mix). It's important to mention that increasing foreign pressures with low coffee prices, or low production of maize, have forced them to make some equivocal decisions like the use of agrochemicals, that kill edible or medicine plants that grow in the milpa, as well as the introduction of hybrids of maize instead of the maintenance of native races. Nevertheless, these are individual, more than collective, decisions that until this moment have not affected their ancestral and cumulative knowledge.

\section{Competing interests}

Both authors declare that they have no competing interests.

\section{Acknowledgments}

Authors thank the authorities of the San Agustín Loxicha municipality, as well as the people of the different communities for all the support in aspects related to accommodation, food and field guides, and the trust for the execution of this work. M.C. Martha Pérez García made a preliminary revision of the manuscript. Jenny helped with the translation. Mariel Støen made a deep second revision and corrected the english. To the following people for identifying the botanical specimens of the following plant families: Asteraceae, José Luis Villaseñor; Fabaceae, Mario Souza, both from the Herbarium MEXU, Institute of Biology, UNAM; Fagaceae, Susana Valencia; other families were identified by Lucio Pérez Lozada and Nelly Diego Pérez, which was carried out in the Laboratory of Vascular Plants of the Faculty of Sciences, UNAM. The identified material was placed in the Herbarium UAM-I. This study is part of the master thesis of the first author. She thanks the Master Program in Botany of the Colegio de Posgraduados and to the National Council of Science and Technology for the scholarship she received during 2002-2004. Part of this project was supported by the Department of Biology at the Universidad Autónoma Metropolitana. Biól. Marco Aurelio Pérez Hernández, for facilitating various administrative procedures. The main support came from the National Council of Science and Technology (CONACyT) (18534R), for the research of "Evaluación de los recursos vegetales de tres municipios Zapotecs en la Sierra Madre del Sur de Oaxaca" 


\section{Author details}

IInstituto de Recursos Naturales, Colegio de Postgraduados, Km. 36.5 Carretera México-Texcoco, Montecillo, Texcoco, Edo. de México 56230, Mexico. ${ }^{2}$ Departamento de Biología, Universidad Autónoma Metropolitana, Avenida San Rafael Atlixco \# 186, Col, Vicentina, C.P. 09340, México, D.F. Mexico.

Received: 11 November 2010 Accepted: 29 February 2012 Published: 12 July 2012

\section{References}

1. Bellón M: Conocimiento tradicional, cambio tecnológico y manejo de recursos: saberes y prácticas productivas de los campesinos en el cultivo de variedades de maíz en un ejido del estado de Chiapas, México. In Cultura y Manejo Sustentable de los Recursos Naturales. Edited by Leff E, Carabias J. México: Centro de Investigaciones Interdisciplinarias en Humanidades, Universidad Nacional Autónoma de México-Editorial Porrúa; 1993.

2. Ohmagari K, Berkes F: Transmission of indigenous knowledge and bus skills among the western james bay cree women of subarctic Canada. Hum Ecol 1997, 25:197-222.

3. Gadgil M, Berkes F, Folke C: Indigenous knowledge for biodiversity conservation. Ambio 1993, 22:151-156.

4. Toledo VM: La perspectiva etnoecológica: cinco reflexiones acerca de las "ciencias campesinas" sobre la naturaleza con especial referencia a México. Ciencias 1990, 4:22-29.

5. Aparicio AB, García E: Percepción Botánica: La visión del mundo natural por los totonacos de Zozocolco de Hidalgo Veracruz, México. Graduate Thesis Escuela Nacional de Estudios Profesionales Iztacala, Universidad Nacional Autónoma de México, México; 1995

6. Berkes F, Colding J, Folke C: Rediscovery of traditional ecological knowledge as adaptive management. Ecoll App/ 2000, 10:1251-1262.

7. Eyssartier C, Ladio AH, Lozada M: Cultural transmisión of traditional knowledge in two populations of north-western Patagonia. J Ethnobiol Ethnomed 2008, 4:1-8.

8. Hunn ES, French DH: Alternatives to taxonomic hierarchy: the Sahaptin case. In Ethnobotany. The Reader. Edited by Minnis E. Norman: Univ. of Oklahoma Press; 2000:118-142.

9. Morris B: The pragamatics of folk classification. In Ethnobotany. The reader. Edited by Minnis E. Norman: Univ. of Oklahoma Press; 2000:69-87.

10. Hunn E: The utilitarian factor in folk biological classification. Am Anthropol New Ser 1982, 84:830-847.

11. Newmaster SG, Subramanyam R, Ivanoff RF, Balasubrammaniam NC: Mechanisms of ethnobiological classifications. Ethnobotany 2006, 18:4-26.

12. Berlin B: Ethnobiological Classification. Principles of Categorization of Plants and Animals in Traditional Societies. USA: Princeton Univ. Press; 1992.

13. Turner N: General plant categories in Thompson (Nlaka'pamux) and Lillooet (Stl'atl'imx). Two interior Salish languages of Brithish Columbia. In Ethnobotany. The Reader. Edited by Minnis E. Norman: Univ. of Oklahoma Press; 2000:69-87.

14. Mapes C, Guzmán G, Caballero J: Etnomicología purepecha. El conocimiento y uso de los hongos en la cuenca de Pátzcuaro, Michoacán. Serie etnociencia. Cuadernos de Etnobiología No. 2. Secretaría de Educación Pública, México; 1981

15. Zizumbo D, Colunga P: Aspectos etnobotánicos entre los Huaves de San Mateo del Mar, Oaxaca, México. Biotica 1982, 7:223-271.

16. Martín G: Ecological classification among the Chinantec and Mixe of Oaxaca, México. Etnoecológica 1993, 1:17-33.

17. Luna-Morales C, Aguirre R: Clasificación tradicional, aprovechamiento y distribución ecológica de la pitaya mixteca en México. Interciencia 2001, 26:18-24.

18. Caballero J, Cortés L: Percepción, uso y manejo de los recursos vegetales en México. In Plantas, cultura y sociedad. Estudio sobre la relación entre los seres humanos y plantas en los albores del siglo XXI Edited by Rendón B, Rebollar S, Caballero J, Martínez MA. DF: Universidad Autónoma Metropolitana-Iztapalapa- Secretaría del Medio Ambiente, Recursos Naturales y Pesca; 2001: 79-100.

19. Ríos MM: Los Zapotecs del Valle Central. In: Etnografía Contemporánea de los Pueblos Indígenas de México. Edited by Secretaría del Desarrollo Social, DF; 1995.

20. Gonzáles RA: Los Zapotecs del Valle Central. In: Etnografía Contemporánea de los Pueblos Indígenas de México. Edited by Secretaría de Desarrollo Social. DF; 1995.
21. López-Franco R: La Etnobotánica en el estudio de los sistemas cognoscitivos populares. Un ejemplo en el área Maya. In Memorias del simposio de Etnobotánica (pp. 100-109). DF, México. Instituto Nacional de Antropología e Historia-Universidad Nacional Autónoma de México. México; 1982.

22. Hunn E: Mixtepec Zapotec ethnobiological classification: a preliminary sketch and a theoretical commentary. Antropológica 1988, 1:35-48.

23. Marcus J, Flannery KV: La clasificación de animales y plantas entre los Zapotecos del siglo XVI. Un estudio preliminar. Cuad del Sur 2001, 7:5-20.

24. Messer E: Zapotec Plant Knowledge: Classification, Uses and Communication About Plants in Mitla, Oaxaca, México. Memoirs of the Museum of Anthropology, University of Michigan, núm. 10, Ann Arbor; 1978.

25. Brown CH, Chase KP: Animal classification in Juchitan zapotecs. J Anthropol Res 1981, 37:61-70.

26. Cruz S, Cruz R: Zoología zapoteca de Santiago Xanica Sierra Sur de Oaxaca. In Etnias, Desarrollo, Recursos y Tecnologías en Oaxaca Coordinated by: González A, Vásquez MA. Oaxaca, México: CIESAS—Gobierno del Estado de Oaxaca; 1992: 117-136.

27. Hunn ES, Acuca D: La etnobiología en el Vocabulario en lengua zapoteca del fray Juan de Córdova, comparación con la actual de san Juan Mixtepec. Cuad del Sur 2001, 7:21-32.

28. Arriaga L, Espinoza JM, Aguilar C, Martínez E, Gómez L, Loa E: Regiones Terrestres Prioritarias de México. Comisión Nacional para el Conocimiento y Uso de la Biodiversidad, México./www.conabio.gob.mx, México; 2000.

29. Luna-José A de L: Cuantificación de los recursos vegetales recolectados en tres municipios Zapotecs de la Sierra Madre del Sur, Oaxaca. Colegio de Posgraduados, Montecillos, México. Programa: Botánica. México; 2006.

30. Aragón M del C: Estructura y composición florística de la asociación selva mediana con pino-encino en Santa Maria Magdalena, Pluma Hidalgo, Oaxaca. Universidad Autónoma Metropolitana-Iztapalapa. D.F., México; 2004.

31. Contreras G: Estructura y Composición Florística de una Selva Mediana de la Sierra Madre del Sur de Oaxaca. Universidad Autónoma MetropolitanaIztapalapa. D.F., México; 2004

32. Hernández M: Estructura y composición florística de un Bosque Mesófilo en la Montaña en la Sierra Madre del Sur de Oaxaca. Universidad Autónoma Metropolitana-Iztapalapa. D.F., México; 2004.

33. Montalvo L: Manejo y estructura de la vegetación leñosa de los cafetales en la Sierra Madre del Sur, Oaxaca. Colegio de Posgraduados, Montecillos, México. Programa: Botánica. pp 100. México; 2006.

34. Cardoso J: Estudio etnobotánico del agroecosistema milpa en el municipio de Candelaria Loxicha, Oaxaca. Universidad Autónoma MetropolitanaXochimilco. D.F., México; 2004.

35. Luna-José $A L$, Rendón $B$ : Recursos vegetales recolectados en diez comunidades de la Sierra Madre del Sur, Oaxaca. Polibotánica 2008, 26:196-242.

36. Aquino $Y$, Rendón B, Rebollar S, Hernández G: Use and conservation of forest resources in the municipality of San Agustín Loxicha, Sierra Madre del Sur, Oaxaca, México. Agrofor Syst 2008, 73:167-180.

37. Secretaría de Gobernación, Centro Nacional de Estudios Municipales, Gobierno del Estado de Oaxaca: Los municipios de Oaxaca. Enciclopedia de los Municipios de México. México: Talleres Gráficos de la Nación; 1988.

38. Instituto Nacional de Estadística y Geogafía: Anuario Estadístico de los Estados Unidos Mexicanos. Directorio Estadístico Nacional de Unidades Económicas (DENUE). http://chat.inegi.org.mx/lib/toc/defaulttoc.aspx? $\mathrm{s}=$ inegi; 2011.

39. FAO/UNESCO: 1976. Mapa Mundial de Suelos 1: 5000 000. vol. III. México y América Central. UNESCO-París; 1995.

40. Dízz Te. El zapoteco miahuateco. Miahuatec Zapotec. http://linguistics. berkeley.edu/ rosemary/miahuatec.htm - 9k - Páginas similares

41. Escobar MDA: Valoración campesina de la diversidad del maíz. Estudio de caso de dos comunidades indígenas en Oaxaca, México. Tesis Doctoral. Doctorado en Ciencias Ambientales, Opción Economía Ecológica y Gestión Ambiental. Universidad Autónoma de Barcelona, España; 2006.

42. Instituto Nacional de Estadística, Geografía e Informática: XII Censo de Población y Vivienda. México: INEGI, México; 2000

43. Alexiades NM: Collecting ethnobotanical data: an introduction to basic concepts and techniques. In Selected Guidelines for Ethnobotanical Research: A Field Manual. Edited by Alexiades NM. New York: Scientific Publications Department, The New York Botanical Garden; 1996:53-94.

44. Instituto Nacional de Estadística, Geografía e Informática: Carta Edafológica, Puerto Escondido D 14-3, escala 1: 250 000. México; 1984. 
45. Instituto Nacional de Estadística, Geografía e Informática: Mapa de Uso de Suelo y Vegetación, escala 1:1000 000. México; 1996.

46. Sillitoe P: An ethnobotanical account of the plant resources of the wola region, southern highlands province, Papua New Guinea. J Ethnobiol 1995, 15:201-235.

47. Brush S: Indigenous knowledge of biological resources and intellectual property rights: the role of anthropology. Am Anthropol 1993, 95:653-671.

48. Krogh L, Paarup-Laursen B: Indigenous soil knowledge among the Fulani of northern Burkina Faso: linking soil science and anthropology in analysis of natural resource management. GeoJournal 1997, 43:189-197.

49. Zent EL, Zent S, Iturriada T: Knowledge and use of fungi by mycophilic society of the Venezuelan Amazon. Econ Bot 2004, 58:214-226.

50. Martínez AMA: Percepción botánica de dos grupos étnicos de la Sierra Norte de Puebla. Am Indig 1987, 47:231-239.

51. Dijk HV, Onguene NA, Kuyper TW: Knowledge and utilization of edible mushrooms by local populations of the rain forest of south Cameroon. Ambio 2003, 32:19-23.

52. CEPEC: Taller de Tradición Oral Una mirada indígena sobre la naturaleza y cultura: la mujer, el oso y la serpiente en mitos nahuas. Cuad del Sur 2003, 9:59-74

53. Borgen L, Dhillion SS, Camargo-Ricalde SL, Rendón-Aguilar B, Heun M: Traditional knowledge and genetic diversity of Opuntia pilifer (Cactaceae) in the Tehuacán-Cuicatlán Valley, México. Econ Bot 2005, 59:366-376.

54. Otero MA: "Diferenciación y flujo génico entre poblaciones de Polaskia chichipe con distintos niveles de domesticación en zonas áridas del centro de México". Tesis de Doctorado. Universidad Nacional Autónoma de México, Campus Morelia, México; 2004.

55. Aguilar-Støen M, Moe SR, Camargo-Ricalde SL: Home-gardens sustain crop diversity and improve farm resilience in Candelaria Loxicha, Oaxaca, Mexico. Hum Ecol 2009, 37:55-77.

56. Cuaderno Estadístico Municipal: San Pedro Pochutla, Estado de Oaxaca. INEGI, México; 1995.

57. Rzedowski J: Vegetación de México. México: Limusa; 1988.

58. Salick J, Cellinese N, Knapp S: Indigenous diversity of cassava: maintenance, use and loss among the Amuessha, Peruvian Upper Amazon. Econ Bot 1997, 51:6-19.

59. De Ávila BA: Clasificación de las lenguas de Oaxaca. In Biodiversidad de Oaxaca. Edited by García-Mendoza A, de Jesus Ordoñez M, Ordóñez M, Briones-Salas MA. Oaxaca: Instituto de Biología-Fondo Oaxaqueño para la conservación de la naturaleza-World Wildlife Fund; 2004:481-539.

doi:10.1186/1746-4269-8-24

Cite this article as: Luna-José and Aguilar: Traditional knowledge among Zapotecs of Sierra Madre Del Sur, Oaxaca. Does it represent a base for plant resources management and conservation?. Journal of Ethnobiology and Ethnomedicine 2012 8:24.

\section{Submit your next manuscript to BioMed Central and take full advantage of:}

- Convenient online submission

- Thorough peer review

- No space constraints or color figure charges

- Immediate publication on acceptance

- Inclusion in PubMed, CAS, Scopus and Google Scholar

- Research which is freely available for redistribution 